\title{
Sustainable rural learning ecologies- a prolegomenon traversing transcendence of discursive notions of sustainability, social justice, development and food sovereignty
}

\author{
D HLALELE ${ }^{1}$
}

\begin{abstract}
This paper contributes, through traversing contested notions of sustainability, social justice, development and food sovereignty, to discourses around creation of sustainable rural learning ecologies. There has always been at least in the realm of scientific discourse, an attempt to dissociate the natural or physical environment from the social and human environment. This trend did not only affect the two spheres of existence only. It is further imbued and spawned fragmented and pervasive terminology, practices and human thought. Drawing from the 'creating sustainable rural learning ecologies' research project that commenced in 2011, I challenge and contest the use of such discourses and argue for the transcendence of such. This would, in my opinion, create space for harmonious and fluid co-existence between nature and humanity, such that the contribution of learning practices exudes and expedites sustainability in rural ecologies.
\end{abstract}

Keywords: sustainable learning environments, rural ecologies, and social justice

\section{Introduction}

In his commentary on Millenium Development goals (May 30, 2013) David Braun laments the inadequacies of the Millennium Development Goals (MDGs) as the United Nations Secretary General presents a report that seeks to chart a new course for sustainable development. In Braun's opinion, the post-2015 "Sustainable Development Goals" (SDGs) must break from failed convention by integrating environmental and social dimensions into the pursuit of economic development aims, acknowledging that our future economic health will critically depend on our planet's ecological health. One of the fundamental, indispensable

1 Dipane Hlalele $(\mathrm{PhD})$ is the programme coordinator in the Faculty of Education at the University of the Free State, Qwaqwa campus. His area of specialization is Rural Ecologies and Email: hlaleledj@qwa.ufs.ac.za. Acknowledgements: The author acknowledges the Nordic Africa Institute for the generous African Guest Scholarship awarded for the period 3 April to 28 June 2013 under the cluster: Rural and Agrarian Change. The funding for the purchase of research equipment and travelling collection in South Africa by the research cluster: Sustainable Development and Poverty Alleviation at the University of the Free State is also acknowledged. The ideas and opinions expressed in this paper are those of the author and may not necessarily be those of the organisations acknowledged. 
and most important facets of sustainable development is learning- which according to the learning ecology framework, over and above acknowledging the existence of lifelong learning, appreciates the fact that individuals learn through participation in different contexts. This paper begins by highlighting the paradigm which guides the critique of the discursive notions addressed, followed by an attempt to crystallize the concept 'rurality' and later provides a prolegomenon traversing transcendence of discursive notions of sustainability, social justice, development and food sovereignty.

\section{Paradigm}

The paper draws from the Critical Emancipatory Research (CER) paradigm. The quote by Fals Borda later in this paragraph signifies a paradigm shift from a conventional and positivistic one that places the 'powerful' researcher at the centre of the research, to one that seeks to present collective research ownership. In my opinion, these notions of power which may have been constructed over time and continue to enjoy some support in some quarters may be deconstructed due to their, in my opinion, cosmetic nature. The quote by Fals Borda (1995:11) below provides an eulogy to and epitomizes such deconstruction:
Do not monopolise your knowledge nor impose arrogantly your techniques, but respect and combine your skills with the knowledge of the researched or grassroots communities, taking them as full partners and co-researchers. Do not trust elitist versions of history and science which respond to dominant interests, but be receptive to counter-narratives and try to recapture them. Do not depend solely on your culture to interpret facts, but recover local values, traits, beliefs, and arts for action by and with the research organisations. Do not impose your own ponderous scientific style for communicating results, but diffuse and share what you have learned together with the people, in a manner that is wholly understandable and even literary and pleasant, for science should not be necessarily a mystery nor a monopoly of experts and intellectuals.

Cosmetic conceptions of power are neither natural nor inevitable, but are, as Dworski-Riggs and Langhout (2010:215) correctly point out, "merely political mechanisms, which could be arranged in other ways". Hayward (2000:78) affirms that the mutable nature of power can lead to political freedom whilst Lybeck (2010:94) deplores the inability of scientists to deconstruct the dynamic social reality that is in front of them because this inhibits the actual study of that reality. According to Horkheimer (1982:47) such scientists/researchers

...experience everything only within the conventional framework of concepts. Any object
is comprised under the accepted schemata even before it is perceived. This, and not the
convictions of men constitutes the false consciousness of today. Today the ideological
incorporation of men into society takes place through their biological preformation for the
controlled collectivity. Even the unique becomes a function and appendage of the
centralized economy.

The choice is informed by CER's objective to engage the marginalised so that their voices can be heard and respected (Dold and Chapman 2011:512). Furthermore, CER advances the agenda of human emancipation regardless of status and strives for the attainment of peace, freedom, hope, social justice and equity in its all forms (McGregor 2003:4). CER's engaging nature which allows for a deeper meaning and for multiple perspectives to be considered (Mahlomaholo 2009:34) will help the citizens to better understand the challenges they face in 
creating sustainable rural learning ecologies. Its empowering and transformative agenda (Nkoane 2012:99), affords the people an opportunity to own the problem and process, and to provide solution(s) to the challenge and also to provide the conditions that will make the solution work.

\section{Rurality}

From a Nordic and/or European frame of reference, the absence of a formal definition of 'rural' led researchers to using 'small' rather than 'rural' (Kalaoja and Pietarinen 2009:109; Hargreaves 2009:117). Kalaoja and Pietarinen (2009:110) note a queer attribute which influence the learning environment. Both teachers and learners experienced a home-like atmosphere and informal personal-relationships. Evidence further suggests that small rural schools offer an effective social context (an ecology) in which learner-centred teaching and meaningful learning processes can be accomplished (Korpinen cited Kalaoja and Pietarinen (2009:114). Most importantly, rural communities in Finland for example, rely on the local school to engage itself in local community events and to cooperate with other public sectors, organisations and people. Not only is the school expected to function as a social agent and to support the social cohesion of the village, but also emphasis is placed on encouraging learners to choose responsible, action-oriented strategies which will solve concrete problems in the local area (Kalaoja and Pietarinen 2002:4).

Earlier work by Marsden (1998:107-117) noted the existence of activities aimed at redefining the roles and development trajectories of different rural areas. There seemed to emerge a trend where rurality-what was termed the 'post-productivist' countryside, or more generally a rural world where the certainties of agricultural production as the traditional 'rural hub' are giving way to a much more polyvalent rural scene and regulatory structure. Marsden's recent work traverses notions of multi-functionality in rural areas. Emerging in the last two decades, the post-productivist paradigm challenges the agro-industrial paradigm through an emphasis on planning for local environmental protection and amenity enhancement. Here agriculture begins to lose its centrality in society, and nature is conceived mostly in terms of landscape value (as a consumption good). Under this model, then, the farm-based approach to the multifunctionality of agriculture is replaced by a land-based approach that emphasizes the different (and demarcated) functions of agricultural land (Marsden and Sonnino 2008: 423).

A further transcendence may be observed in instances where rurality was regarded as a concept which was understood with reference to rural, areas as natural or geo-physical spaces. The government of South Africa view "rurality" to mean "a way of life, a state of mind and a culture which revolves around land, livestock cropping and community". Rural areas include all traditional communal areas, farmland, peri-urban areas, informal settlements and small rural towns where people have a number of possibilities to live from the land. Rural development is about enabling rural people to take control of their destiny, thereby dealing effectively with rural poverty through the optimal use and management of natural resources. It is a participatory process through which rural people learn over time, through their own experiences and initiatives, how to adapt their indigenous knowledge to their changing world (Department of Rural Development and Land Reform 2010:12). It is clear that more emphasis in this discourse is on the people (i.e., the social space) as it is complemented by the geo-physical space. 
Rural occupation in South Africa (SA) is directly linked to apartheid and the colonial policies of dispossession, resettlement and a systematic exclusion from opportunities and SA is characterised by diverse rural areas. Key features of a rural profile in South Africa include: long distances to towns; the poor conditions of roads and bridges to schools; a lack of or limited access to Information Communications Technologies (ICTs); a lack of services such as running water, electricity, sanitation, health and educational facilities; low economic status and little access to lifelong learning opportunities. One of the most pervasive features of rural communities is poverty (Department of Education, 2005:7). Food security and the cost of education are also major problems. Furthermore, rural communities are characterised by high illiteracy levels. Continued under-resourcing of schools relative to need further compounds the problems of rurality. The government's commitment to equal and fair treatment unfortunately has yielded meagre change for rural schools. In relation to education, lack of basic services (water, sanitation, etc.) affects access to and the quality of education, such as inadequate infrastructure in schools (buildings, ICTs, etc.) and the long distances learners must travel to schools. The attributes of rurality that adversely affect the quality of education include: a lack of qualified teachers, multigrade teaching, unreasonable teacher-learner ratios, irrelevant curricula, and competing priorities between accessing education and domestic chores, while the teaching staff seem to be imbued with poor morale and motivation. Teachers may be unwilling to move to rural areas where social and cultural opportunities are limited and salaries may not contain an enticement peg. Even when teachers are willing to work in rural areas, working conditions are likely to make them reluctant to stay for the long term (Mollenkopf 2009:xiii). The discussion above sharply verifies the deficiency approach with which the rural areas have come to be almost synonymous. Hlalele (2012:112) challenges the deficiency approach by providing an asset-based picture of what may have sustained education in rural contexts over time. According to Malhoit (2005:21), the school is the most important public institution in a rural community and also represents the economic lifeblood of the economy. A few other attributes (DoE 2005:7; Malhoit 2005:21; Ludlow and Brannan 2010:4).

\section{A learning ecology framework}

There have been some disputes around the notion of confining the learning process to time and space. However, some dissenting discourses were also noted. I subscribe to Barron's (2004, 2006) notion of learning as an activity that takes place within, between and across contexts (constituting a learning ecology). An ecology, therefore, may be construed as an environment that fosters and supports the creation of communities. It is further defined as an open system, dynamic and interdependent, diverse, partially self-organizing, adaptive, and fragile (Looi 2001: 14). There exists a learning ecology which is an environment that is consistent with how learners learn. Barron (2006: 195) defines a learning ecology as a set of contexts found in physical or virtual spaces that provide opportunities for learning. It encompasses different activities, material resources, relationships, and the interactions that emerge from them. The ecology is extended to include the following characteristics of a learning ecology; a collection of overlapping communities of interest; cross pollinating with each other; constantly evolving; and largely self-organizing. In more formal education environments, the concept of self-organizing gives way to a more structured process for knowledge transmission where the role of an educator is to facilitate (Siemens 2003:5). Visser (1999, cited in Siemens 2003:6) adds that the learning ecology involves a setting in which learning communities come into being, evolve, die, regenerate and transform. We may not 
deny the fact that the notion of learning ecology as is depicted in this chapter, presuppose the observance and most importantly, transcendence of the well-known geo-physical space. For a learning society, interpreting, understanding and assessing its learning ecology first begins with contextual vision-building. In each ecology, individuals and collectives would come together to co-create their vision of how they want to live and learn together, both in the present and in the future. This vision would be based on the unique contexts of that ecology, the unique personalities of the people, and the unique energy and spirit that emerges when they come together in relationships. The questions asked would be more like: "Who are we?"; "What values are important to us?"; "Where are we going and why?; What kind of world do we want for our children and grandchildren? And later, "How do we get there?" (Williams, Karousou and Mackness 2011:22). Drawing on the authors' (Williams et al) illumination of the learning ecology, our understanding of the concept of learning is underpinned by the following key elements:

- Learning is rarely linear or planned; it is messy, organic and often spontaneous;

- Learning occurs in authentic interactions and partnerships, which emerge through varied self-organizing processes;

- Learning is unique to the person and the context; it cannot be replicated, because no two learning spaces or relationships are alike;

- Unlearning, self-learning, co-learning are all vital and integrated aspects of a learning ecology;

- Learning grows from a dialogue between meaningful questions and practical mistakes

Using an ecological metaphor, the learning environment is likened to the biosphere, and the learning ecology is to learning what the biosphere is to life. Therefore, it should be comprehensible to assume that learning generates and builds upon complex and diverse networks/webs of human existence. To sum up, Seepe (2004:9) reminds us of the African social philosophies such as Ubuntu. Ubuntu presupposes not only a conscious, deliberate, internalized, and pervasive focus on the self in the environment, and the self in the community from an African perspective, but to the extent to which these develop an ecological awareness, or self-as-part-of-environment.

\section{Learning for sustainability}

"We live in turbulent times; our world is changing at accelerating speed. Information is everywhere, but wisdom appears in short supply when trying to address key interrelated challenges of our time such as; runaway climate change, the loss of biodiversity, the depletion of natural resources, the on-going homogenization of culture, and rising inequity. Living in such times has implications for education and learning"(Wals and Corcoran 2012).

Drawing from one of the latest books on education and learning in the context of sustainable development - Learning for Sustainability in Times of Accelerating Change (Wals and Corcoran 2012) - it can be observed that the speed of change, physically, socially and culturally, is accelerating. Continued globalization and digitalization are not only affecting how we think, what we know, who to believe, how we act, they also affect the role of education in society. The role of science in society, for example, is also changing drastically. Science is no longer the authority of truth, if it ever was. It just represents one point of view or an opinion in the public debate of controversial and/or ambiguous issues. Whilst globalization and 
digitalization continue to flood (and maybe drown) humanity with information at an alarming rate, Wilson (1998:99) cautions that the enormous amount of information does not automatically lead to wisdom. When we try to address the key challenges of our time, it is above all 'wisdom' that we need. There is anecdotal evidence to suggest that in some of the poorest communities, people spend the little income they have (...maybe from government grants) on 'feeding' the phone. The cell phone has become a prestigious status symbol that feeding the phone comes before feeding the children. This discussion in this paragraph evokes some desire to explore the possibilities of (re)designing, strengthening and facilitating change-based learning and transitions towards sustainability. Examples of such learning include learning by doing, social learning, transformative learning, cross-boundary learning, service learning, learning from and with nature, etc. Thinking anew (transcendence of...) the status quo implies:

- Reflecting on what it means to educate and learn for sustainability- considering the kinds of personal and collective qualities that need to be strengthened in order to our learners and the wider society to contribute to a more sustainable world.

- Challenging the concept of 'sustainability competence' by referring to qualities like: thinking in a forward manner (anticipatory thinking), seeing relationships and interdependencies (systems thinking), the ability to put yourself in the minds of others (empathy and open mindedness), utilizing diversity towards creativity, and coping with uncertainty.

- Suggesting how we can re-orient, re-connect, and re-imagine learning processes in a manner that both expedites and exudes sustainability.

Sustainable development involves processes of change in society that contain at least these three dimensions. Systems thinking - seeing connections, relating functions to one another, making use of diversity and creating synergy - may offer support in realizing a society that is more sustainable than is presently the case or that we currently anticipate. Apparently it is very important that we understand systems of communities and that we begin to think (again) in terms of relations and connections. We can learn a lot from eco-systems in our quest for sustainability. Eco-systems are based on networks, mutual dependency, flexibility, resilience and, if we add it all up: sustainability (Wals, van der Hoeven and Blanken 2009:7).

Chilisa, Mafela and Preece (2003:76) posit that sustainable development is commonly associated with environmental sustainability and the sciences. Yet education is the means by which we learn about our cultural heritage and our values. It is the means by which we transform all forms of knowledge through generations. The authors (Chilisa et al.) conclude that it is time therefore, to raise the profile of education to sustainable development. According to Hansom (2003:37) attention needs to be paid to different discourses about sustainability: the distinction between the discourses associated with a weak and strong conceptualization of sustainability. The two were once referred to as 'technological' versus 'ecological' respectively (Orr 1992, cited in Hansom 2003:11). Drawing from the strong conceptualization, development is said to be sustainable as long as the 'natural capital', i.e., the biophysical basis for the production of goods and services, is not declining. On the contrary, the weak conceptualization implies that 'human capital' (scientific knowhow, industrial infrastructure and human prowess) may substitute the loss of natural capital. However, eclectic philosophies would propose the harmonious co-existence, complementarity as well as recognition of the added value of each of the role players. Within this harmonious co-existence, I would like to illuminate the process of acquisition of the scientific knowhow- 
which has, as its indispensable and rudimentary antecedent, the process of sustainable learning.

According to Halsey (2009:3) there is diversity of thinking about the concept of sustainability. John Halsey sees exploring new relationships between rural education and sustainability as having the potential to arrest, or at least influence, the continuing marginalisation of rural education in relation to contributing to the future of a country. Rural education, in his (John Halsey), view working with other essential human services like health and local government and the private sector to address the challenges of sustainability and, through this, reinvigorate rural education. Following her analysis of the possibility of "'ordinary' landscapes or communities within which we live, work and educate" to reinvigorate ways of shaping the future, Allison (n.d., cited in Halsey 2009:4) concludes that "sustainability immediately shifts the perception of 'ordinariness' of these ... landscapes" and opens the way to new possibilities.

It has been noted that many rural areas are struggling to remain viable in relation to essential human services like education and health, in the face of rising costs per unit of services required (as defined by certain views of economic costing and benefits), and the pervasive impacts of globalization on rural economies, amongst the most visible of which is a steep decline in the demand for traditional labour (McSwan 2003, in Halsey 2009:6). "Globalization and the power differentials it creates have had a significant social and economic impact on rural areas, while major cities have benefited from the focus on the knowledge-based production that global capitalism demands, drawing in capital, people and resources" (Alston and Kent 2003:5, cited in Halsey 2009:6). Next, sustainable rural learning ecologies are interrogated from a social justice perspective.

\section{Social justice as an indispensable facet of sustainable rural learning ecologies}

Kose (2009:631) opines that some scholars argue against a definitive and universal conceptualisation of social justice, whilst many argue that social justice has to do with "recultivating individual and institutionalised practices rooted in low expectations, deficit thinking, marginalisation and cultural imperialism" (p.630). It can therefore be accepted that a general definition of social justice is hard to arrive at and even harder to implement. In essence, social justice is concerned with equal justice, not just in the courts, but in all aspects of society. This concept demands that people have equal rights and opportunities; everyone, from the poorest person on the margins of society to the wealthiest, deserves an even playing field. According to Gerwitz, Ball and Bowe (1995:129), theories of social justice advocate adequate mechanisms used to regulate social arrangements in the fairest way for the benefit of all. For the purpose of this chapter, conceptualisation of social justice hinges on Nancy Fraser's definition. She defines justice as "parity of participation" (Tikly 2010:6). Fraser (2008:16) elucidates that "overcoming injustice means dismantling institutionalised obstacles that prevent some people from participating on a par with others as full partners in social interaction". Gerwitz (1998:469) maintains that social justice is premised on the discourse of disrupting and subverting arrangements that promote marginalisation and exclusionary processes. Social justice supports a process built on respect, care, recognition and empathy. The presence of words, such as 'demands, mechanisms, disrupting, subverting' in the definitions above, suggest concerted action and seem to elicit revolutionary overtones. 
Similarly, Calderwood (2003:309) also adopts a revolutionary approach to social justice. She posits that it works to undo socially created and maintained differences in material conditions of living, so as to reduce and eventually eliminate the perpetuation of the privileging of some at the expense of others. Frey, Pearce, Pollock, Artz and Murphy (1996:111) raise concern about sensibility toward social justice. The authors (Frey et al.) claim that sensibility should forego ethical concerns, commit to structural analyses of ethical concerns, adopt an activist orientation and seek identification with others. Regarding the promotion of social justice, Calderwood (2003:308) is of the view that people need to act to reduce and eradicate oppression, however distant we may feel from the personal culpability of its enactment. The view is further emphasised by former British Prime Minister, Gordon Brown, who, quoting an unknown Greek philosopher, said: "When will there be justice in Athens? It will be when those that do not suffer are as angry as those that do". Undoubtedly, there seems to be an agreement that injustice is not only an issue that concerns those at its receiving end, but also those members of society that do not seem to be affected. The situation seems to further call for alertness or what we may call thinking beyond the visible and the ordinary. Calderwood (2003:311) cites an unfortunate reality about social justice. She states that the mechanisms of injustice are largely invisible, even to those who strive to live their lives and carry out their work ethically. The question that may arise from the ensuing debates above is whether or not and to what extent providers (policy makers and administrators) are aware of the practices, processes, rules and regulations that perpetrate and perpetuate acts of social injustice and thus consider themselves as culpable. Summarily, social justice can be construed as "the exercise of altering institutional and organisational arrangements by actively engaging in reclaiming, appropriating, sustaining, and advancing inherent human rights of equity, and fairness in social, economic, educational, and personal dimensions" (Goldfarb and Grinberg 2002:162).

Questions relating to the proper distribution of benefits and burdens among sites have always posed a challenge for education institutions. Fraser's perspectival dualist framework troubles the disparate distribution of goods and services and/or social structures that enable material inequality (North 2006:509). Fraser (1997:28) asserts that the increasing stress on sectoral politics undermines redistributive efforts that seek to improve the well-being of marginalised citizens. Her perspectival dualist framework views recognition and redistribution as the cofundamental and mutually irreducible dimensions of justice. Social justice works to undo socially created and maintained differences in material conditions of living, so as to reduce and eventually eliminate the perpetuation of the privileging of some at the expense of others (Calderwood 2003:307) In order to promote social justice, we must act to reduce and eradicate oppression, however distant we may feel from personal culpability for its enactment. Unfortunately, the mechanisms of oppression are largely invisible, even to those of us who strive to live our lives and carry out our work ethically (Solomon and Murphy 2000:44).

Sabbagh (2003:263) indicates that distributive justice includes at least three major components: the normative patterns that regulate resource distribution (i.e., justice principles and their derivative rules); the classes of social resources that are being allocated; and the valence-positive or negative- of the expected distribution outcomes. Arguments in this paper adopt a moral community perspective, viewing responsibility and care among members as central to social justice. Social activists advocate the need for social change in rural areas which is linked to social justice, using a process that is consultative, collective, participative and empowering. Connectedness and responsibility enrich the notions of fairness, and equality, thus extending the baseline of ethical practice (Lloyd 2000:97). 
According to Frattura and Tropinka (2006:327) critical theory integrates the value of social justice into the practice of research for reform. How injustice and subjugation shape people's experiences and understanding of the world constitutes the focus of critical theory. A critical theory perspective concerns itself with issues of power and justice and the ways that the economy, matters of race, class and gender, ideologies, discourse, education, religion, and other social institutions interact to construct a social system. Inquiry that is critical should be connected to an attempt to confront the injustices of society. Kellner (cited in Frattura and Tropinka 2006:332) comments that what makes critical theory critical is not just the study and understanding of society, but also critiquing and changing it. No social arrangements are viewed as neutral, but rather as artificial constructs structured to benefit one segment of society over another. Conventions, constitutional obligations, and requisite rights around education rights often permit individuals and groups to hold governments accountable for the progressive realisation of rights (Spreen and Vally 2006:356). Keet (cited in Spreen and Vally 2006:357) examines the contradictions in the human rights discourse of education rights as a public good in 'an age of markets'. Focusing on South Africa, he shows (1) how 'educationas-a-human-right' remains elusive and (2) why it has failed to prevent the increasing commodification of education and the attainment of social, economic and environmental justice. The failure of education policies and laws to ensure the attainment of education rights for the majority of South Africans, including the rural inhabitants is an immediate challenge. Bryant (2010:55) asserts that one of the primary obstacles of rural education is wilful ignorance, particularly on the part of governments, of the conditions in rural areas and schools. Wide disparities in access to quality education continue to plague rural areas (McQuaide 2009:17). Malhoit (2005:22) posits that society's obligation to educate learners should not depend on a child's demographic good or bad fortune; nor should geography dictate a child's educational destiny.

Despite all the efforts deployed by countries of the world and the vigorous mobilisation of international communities, rural people lag far behind in education and are particularly hard hit by poverty and hunger. Poverty, hunger and underdevelopment are holding back educational development (Sauvageot and da Gra $\bowtie$ a 2007:47) and the creation of sustainable rural learning ecologies. From an ecological perspective, I would argue that unsustainable educational endeavours in rural ecologies lead to poverty, hunger and underdevelopment.

\section{Development in sustainable rural learning ecologies}

The advent of democracy in South Africa created new thinking around issues of rural development and the provision of education in rural areas. A new political regime with its new policies clearly requires some new strategies to begin to solve the immense rural development challenges and also to understand better the dynamics and needs of rural communities. Such an approach is clearly informed by the experience of other African countries and the failure of many rural development strategies within them. There is great urgency in South Africa to implement policies leading to empowerment of the people, whilst promoting rural development and establishing a basis for the sustainable use of available human and natural resources. This would represent a major departure from earlier approaches and would hopefully strengthen the ideals of democracy and transparency which are gradually developing in the 'new' South Africa. Marianne Solberg (2012, cited in Arnason 2013:1) states that educational provision needs to embrace flexibility and focus on serving the rural 
areas. Such education programmes are likely to contribute by supplying a skilled workforce ready to contribute to the development of rural areas, slowing down emigration, increasing innovation, circumventing social and geographic inequality, supporting democratic participation, as well as spurring personal development. Solberg' (2012) contention on the provision of education geared at rural development may be seen as a lifeline for both sustainability and development in rural ecologies.

To assist with this transformation process and to incorporate rural people fully, it is believed that participatory tendencies provide a vital approach in appreciating the views and skills of rural people and in formulating locally appropriate development strategies. Thus far, however, relatively little has been written about the current and potential application of rural participation in the context of rural development in South Africa. Rural development strategies therefore need to factor in issues of social mobilisation of rural communities to ensure that they take centre stage in the improvement of their own quality of life. In order to ensure that all social mobilisation initiatives consider the dynamics of particular communities, a detailed household profiling precedes any initiative. Profiling of households needs to be followed by the mapping of assets in an ecological setting.

\section{From food security to food sovereignty}

One, probably the most pressing issue, according to Halsey, is food security. The choices we make about food affect both us, intrinsically, and nature, extrinsically. In effect, we eat the view and consume the landscape. Ensuring that a country attains and remains food secure is something which cannot be ignored. Changes over time and the impacts of climate change may lead to the emergence of new problems. These changes, and others that food production and distribution are reliant on require the re-alignment of program offerings for rural education, rural educators and rural communities (Halsey 2009:9). For continued existence (sustainability), rural ecologies need to 'mutate'. Depletion of fossil-based energy sources, for example, provides a relevant example of diversification for the sake of sustainability. Some rural (and other) schools/colleges/institutions are already embracing solar technology, and the scope for a greater role nationally in terms of direct contributions to the nation's energy requirements. This includes rural schools taking a leading role in developing curriculum and certification to ensure there is expertise available where and when it is needed to help grow and drive the green revolution.

Assuring fresh water supplies which have their headwaters in rural locations and traverse substantial rural landscapes entails ongoing investment, human intervention and management. Drought experienced in many parts of the world, coupled with existing arid areas, pose a threat to continued existence of rural ecologies. It would therefore not be unwise to link learning and water sustainability. Improving the viability (sustainability) of rural learning ecologies by increasing enrolments from sources outside of usual catchment areas and increasing the pool of youth positively disposed to a career/ employment in rural areas through first-hand experience of them. To sum up, learning in rural areas needs to ground itself on the notions of 'national food security, sustainability and economic efficiency' (Du Toit 2013).

A conventional idea of a sustainable fishery is that it is one that is harvested at a sustainable rate, where the fish population does not decline over time because of fishing practices. 
Sustainability in fisheries combines theoretical disciplines, such as the population dynamics of fisheries, with practical strategies, such as avoiding overfishing through techniques such as individual fishing quotas, curtailing destructive and illegal fishing practices by lobbying for appropriate law and policy, setting up protected areas, restoring collapsed fisheries, incorporating all externalities involved in harvesting marine ecosystems into fishery economics, educating stakeholders and the wider public, and developing independent certification programs.

Some primary concerns around sustainability are that heavy fishing pressures, such as overexploitation and growth or recruitment overfishing, will result in the loss of significant potential yield; that stock structure will erode to the point where it loses diversity and resilience to environmental fluctuations; that ecosystems and their economic infrastructures will cycle between collapse and recovery; with each cycle less productive than its predecessor; and that changes will occur in the trophic balance.

There is an emerging desire amongst scholars and rural dwellers alike, for transcendence from the notion of food security to that of food sovereignty. According to the International Planning Committee for Food Security (2007) and Lee (2007) food sovereignty is the:
right of people to healthy and culturally appropriate food produced through ecologically sound and sustainable methods, and their right to define their own food and agriculture systems. It puts the aspirations and needs of those who produce, distribute and consume food at the heart of food systems and policies rather than the demands of markets and corporations. It defends the interests and inclusion of the next generation. It offers a strategy to resist and dismantle the current corporate trade and food regime, and directions for food, farming, pastoral and fisheries systems determined by local producers and users. Food sovereignty prioritises local and national economies and markets and empowers peasant and family farmer-driven agriculture, artisanal - fishing, pastoralist-led grazing, and food production, distribution and consumption based on environmental, social and economic sustainability. Food sovereignty promotes transparent trade that guarantees just incomes to all peoples as well as the rights of consumers to control their food and nutrition. It ensures that the rights to use and manage lands, territories, waters, seeds, livestock and biodiversity are in the hands of those of us who produce food. Food sovereignty implies new social relations free of oppression and inequality between men and women, peoples, racial groups, social and economic classes and generations.

Transcendence of the discourses of food security to those of food sovereignty depicts a remarkable shift as it, amongst others, relocates power in the hand of the rural inhabitants and further challenge their conscience and resolve in dealing with the ecology such that harmonious, mutual and reciprocal co-existence obtains. According to Reem Saad, an Egyptian professor of anthropology and a researcher, "we seem to be talking a lot about food security without really paying enough attention to the crucial factor of food sovereignty, which is an even more crucial matter." Food sovereignty invariably provides space for learning for sustainability and it builds and promotes local knowledge and skills that conserve, develop, and manage localizing food systems is supported. 


\section{Discussion}

The outmigration from rural areas has not abated. Many rural areas continue to experience a decline in inhabitants (Alliance for Excellence in Education 2010). The majority of the rural emigrants are generally the working group with a fairly higher level of education and who were most likely, to contribute a lot more than the youth and aged. The aged were found to have strong links with the place and space and therefore less likely to move. In some cases the youth move, some returning over weekends, in search of better education. The fact that many rural learning ecologies do not have secondary schools, mainly as a result of fewer learners, was also confirmed. One of the parents said: "Unlike me, my children deserve a better education so that they can have a better future. I will do everything in my power in order for them to realize their dreams. However, I am worried that they may not come back to stay here. The way I see it, the education they get here does not prepare them for meaningful contribution to rural development. They are not taught how to milk.... and plough... read and write ...they can". In many districts, schools with a lower number of learners are either closed down or amalgamated.

The "ideal" rural teacher can teach multiple grades or subjects, organize extracurricular activities, and adjust well to the environment and the community (Brown 2003). Changes of having such a situation are better in areas where the teachers stay in the particular rural ecology (Personal observation in one rural Swedish ecology). It is extremely difficult to find teachers who fit in with the rural community and will stay for a long period of time because of this. Usually the teachers who end up staying are either from a rural background or have previous experience with rural communities. Bull, Warner, Yellin, Robinson and Neuberger noted over two and a half decades ago (1989) that disciplines such as law, medicine and architecture introduced changes in the programmes to address the availability of staff that will service and impact the rural areas. To their (Bull et al.) surprise, only the education profession had resisted such changes. In my observation, that status quo largely continues to prevails. For multi-campus teacher education programmes, it is expected that the student who did a course on any of the campuses should be subjected to the same course content, leaving very little or no room at all, for flexibility and diversification in respect of a particular learning ecology. Exposure of student teachers to rural learning ecologies appear as 'funded projects', for example the Rural Teacher Education project at the University of Kwazulu Natal.

As with rural teachers, rural learners should be in a position to make decisive contribution to sustainability and development in the community in order to get accustomed to the environment and feel a sense of shared wealth. Families and communities are crucial to the educational progress of rural youth (Brown 2003). In order for rural communities to succeed, they must allow members to have good paying jobs, access to health care, quality education, and strong community ties. Additionally, rural communities need programs to build a stronger sense of togetherness. Social interaction affects the behavior and development of relationships among groups of people with the same territory. Shamah and Mac Tarvish (2009) observed that rural residents often see the skills necessary for their own success as unique from the skills that are valued in urban environments. In Learning to Leave, Corbett (2007) describes the ways this disconnect emerges in Nova Scotia and why it is a critical issue that must be given greater attention. His work reveals that rural schools generally teach students in ways that build an urban skill set through emphasizing mastery of academic skills necessary in structured office professions. 
Responsive curricula: Here the notion of content versus context comes to the fore. In some instances there is a match between the two whilst instances of mismatches have also been recorded. One example was provided by a community member and teacher in one of the Swedish rural ecologies who stated that "...there was a stage where many learners in one of the high schools in my area had a predetermined goal of perpetuation the family farming legacy and school programme was not responsive to that. The learners concerned indicated how irrelevant the content they were learning at school was. The content did not only address the glaring need of the local economy at the time, but was also oblivious to their intended careers and wishes" (Pers. Comm. 29 May 2013).

Internal versus external locus of control: Locus of control is a social psychology concept that refers to the extent to which individuals believe that they can control the events that affect them. Whilst external locus of control attributes outcomes of events to external circumstances, internal tends to attribute outcomes of events to their own control. There is also evidence in clinical research that internality correlates negatively with anxiety, and that internals may be less prone to depression than externals, as well as less prone to learned helplessness. Whilst these concepts were originally meant for understanding individual behavior, they also apply to collective behavior (Judge, Erez, Bono and Thoresen 2002:694). For example, in the village of Muyexe [one of the inter-agency development project the South African government has embarked upon] the community resorted to their own wisdom and innovation when the bakery faltered on delivering bread for learners. The community resorted to their traditional furnaces/ovens to provide bread for the children. These furnaces/ovens are made out of mud and they have a space/compartment for fire.

Limited knowledge/awareness about rural realities: Historically, rurality and rural education have been marginalised bodies of knowledge in South Africa and little is known of the focus of the various studies and the state of rural education and rural education research (Nkambule, Balfour, Pillay and Moletsane 2011:341). Over and above what Nkambule et al (2011) suggest, i.e., little is known about rural research, the little knowledge that authorities have seem to take a long time to be acted upon. One of the problem areas in rural education is multigrade teaching. Ms Tsakani Chaka, Researcher at the Centre for Education Policy Development (CEPD), presented a study into teaching literacy and numeracy in multigrade classes in rural and farm schools in South Africa to the Parliamentary Monitoring group on 6 March 2012. She noted that in 2005, the Ministry of Education released a report on rural education which specifically noted multigrade teaching as a challenge in rural and farm schools. This research followed up on the position at the moment, and analysed data as well as carrying out six case studies, in the North West province, using interviews with principals, interviews with teachers, lesson observation, documentary analysis (work schedules, lesson plans, time-tables, learners' work), interviews with , the interview with provincial and district officials, as well as with teacher trainers. About $27 \%$ of schools had multigrade classes, and this involved about $4 \%$ of the learners. The multigrade system, although in fairly widespread use, was not actually formally recognised. Most of the schools that had these classes were poorly resourced. There was no curriculum adaptation, and the planning requirements were the same as those of the monograde classes. Teachers' exposure to suitable teaching strategies was limited, there was no specific teacher training on multigrade teaching, and no specific support was offered to these teachers. The teachers faced high workloads owing to planning and assessment requirements. The learning materials were not always available in the mother tongue, and were not suitable for self-study. The continued neglect of the multigrade 
problems contributed to ongoing marginalisation of the poor, for whom multigrade schools were a reality.

\section{Prospects}

Mapping and maximizing inherent assets in rural learning ecologies: According to Solomon (2012:11-14), the inherent assets of rural schools and communities provide a strong foundation for progress. These advantages include increasing access to innovative technology, distance-learning and place-based learning opportunities, and high levels of volunteer support from parents as well as members of the ecology. Along with appropriate and adequate backing from state and national leaders, rural schools have tremendous potential to ensure that all of their students graduate ready to succeed in college and careers [including in rural ecologies]. It is thus possible to simultaneously utilize and enhance various resources/asserts. This also helps to minimize dependence on external resources and institutions. Interactions among stakeholders can be guided by the 'internal logic' and priorities of the learning ecology rather than these being externally determined. The learning processes will strengthen local institutions and civic capacity for collective action, ideally to move forward together toward a shared vision. Collective participation can facilitate local management of the shared vision, thereby strengthening civil society and increasing active involvement. Collectives that articulate and pursue their own goals and priorities are more likely to expand livelihood opportunities, and do so in a sustainable manner. Mapesela, Hlalele and Alexander (2012:95) concur with sentiments of proponents who strongly advocate the enhancement of selfreliance. Internal challenges to the success of a self-reliance strategy stem from violations of the assumptions that: members share common interests and consensus is central to sustainability; inclusive participation and democratic decision-making within the community are necessary and possible; and sufficient autonomy exists for people to influence their learning ecology's future.

Providing responsive and demanding educational programmes: Many rural schools are already setting high expectations for every student and ensuring that all standards, assessments, and accountability systems reflect the high-level skills and knowledge all students need. To help meet these standards, an increasing number of rural schools are employing cutting edge technologies and other distance-learning opportunities to expand the availability and choice of rigorous programmes. Rural schools are pioneers in the expansion of local place-based learning, rigorous, hands-on learning opportunities that provide real-world relevance to improve academic performance. Despite these innovations, however, too many rural high schools still lack the funding, personnel, and technological infrastructure to provide students with rigorous high-level coursework, a vital prerequisite for career success (Solomon 2012:15).

Recruiting and retaining highly effective teachers (Grow-your-own-timber!): Successful rural high schools are able to ensure an adequate number of high-quality teachers to boost academic success. Unfortunately, too many rural communities struggle to find and keep effective teachers. Even though rural teachers generally report a higher level of job satisfaction than their urban and suburban counterparts, rural communities have a higher number of lessqualified teachers and often lose their most experienced employees to higher-paying posts in nearby suburban and urban areas. Despite these ongoing challenges, however, an increasing number of rural communities are addressing these difficulties head-on with advanced technologies and distance learning that allow teachers to expand their professional 
development opportunities, as well as "grow-your-own-timber" programs that encourage talented young people to stay and teach in their home communities (See UNISA 2011).

Building viable models of community support and partnerships: Rural communities play a vital role in the success or failure of their local schools. High-performing schools tend to depend on local community-based services, businesses, and other non-academic partners to stretch limited resources and support a common vision for change. Rural high schools often have the benefit of small, tight-knit communities to help guide school improvement efforts and participate regularly in school activities. Unprecedented and widespread reliance on technology may also allow rural schools to engage local stakeholders in educational goals and outcomes more broadly than ever (Solomon 2012:47). Unfortunately, some rural ecologies may still lack the tax base, stable local economy, and sufficient social and community capital to invest adequately in sustainable endeavours. In areas that have lost a large number of young people and highly educated professionals to better paying jobs in nearby cities, retaining broad-based community support is also an ongoing challenge.

Provide space for appreciation and better understanding of rurality: In my opinion, there seems to be a reasonable expectation that rurality as a way of life has not, at least in some quarters, been fully understood, valued and appreciated. This may be evident in the notion of thinking that one's life is complete if it is in an urban area. Eppley (2009:9) states that rural teachers have a special obligation to awaken students to the concept of sustainability and to help them develop and nurture a sense of place. This is an urgent requirement of the rural highly qualified teacher and has little to do with test scores and certifications, and everything to do with nurturing students and sustaining communities.

Creating and sustaining learner support networks: Strong rural schools ensure that all learners have access to rigorous and option-based courses of study and connect young people with a broader range of social supports to address problems inside and outside of the classroom. The establishment and perpetuation of multi-modal, multi-sectoral networks and partnerships for learners in rural ecologies are more likely to contribute to the development of such ecologies. In many rural ecologies the absence of career and lifestyle information may impact negative on demands of sustainability and development (Solomon 2012:49).

Harmonizing content and context: Robinson et al. (2004:3) found that localised curriculum of the rural schools that utilised local environment as curriculum, lead to positive motivation, interest and participation. Shibeshi (2006:12) suggested that policies and strategies addressing the education needs of rural people should accommodate the needs of rural people in their diversity (agro-ecological, geographical as well as socio-economic and cultural) through a range of modalitites. These include distance education; non-formal education programmes; school feeding programmes; strengthening early childhood care and education; establishing feeder school clusters; promoting multigrade classroom learning; rethinking teacher education, development, recruitment and retention strategies; and promoting vocational education for rural development and sustainable livelihoods.

Building rural community resilience and capital: Wright (2012:49) states that communities must be resilient to be sustainable. Resilience results as relationships among community members develop. It is the "bridging social capital" between heterogeneous groups, referred to by Putman (1995, cited in Wright 2012:50). It may be reasonable to expect that close interpersonal connections usually develop in smaller and rural communities because they are places where individuals know, share with, and care for one another. Rural schools mirror 
these qualities, and have a responsibility to help develop these healthy relationships through getting to know the groups and individuals within their community, and sharing with them a collective sense of purpose. At this stage, it may be worthwhile to mention the gratifying instance where the Muyexe community resorted to their own capital when bread was not delivered for the children at school.

\section{Conclusion}

In this article I critically looked at the sustainable rural learning ecologies in relation to conventional discourses of sustainability, social justice, development and food sovereignty and suggested that such notions no longer hold as they were initially conceptualised. I showed how each of these may be transcended. Appreciation of rural learning ecologies (recognition of its wealth/assets) may be what is required to circumvent notions of human completeness or self-actualization only when one is in an urban area. The paper further alluded to the fact that rural may not necessarily be conceived as 'un-urban' and vice versa. It may further be concluded that the voice, wisdom and capabilities of rural inhabitants need to be respected. In the course of history, seldom has the greatness of a nation long survived the disintegration of its rural life. For untold ages man by nature has been a villager and has not long survived in other environments. Many studies of the subject which has been made in Europe and America have revealed that as rule city families survive for only a few generations. Cities continue to grow and thrive only as they are constantly replenished from the rural population. So long as a nation's rural life is vigorous it possesses reserves of life and power, which nourish, nurture, promote and sustain humanity. When for a long time cities draw the cream of life and culture from the villages (rural brain drain), returning almost nothing, as has been the case in some parts of South Africa and the world, the current rural resources of culture and energy become depleted, and the strength of the nation is most likely to be shaken and stirred.

\section{References}

Alliance for Excellence in Education 2010 (29, September). Paving the rural road to high school success. http://all4ed.org/paving-the-rural-road-to-high-school-success. Accessed October 9, 2013.

Arnason H 2013. Can distance education support rural development? Paper presented at the Fifth Nordic Conference on Adult learning in Reykjavik 3-5 March 2013

Barron B 2004. Learning ecologies for technological fluency in a technology-rich community. Journal of Educational Computing Research, 31, 1-37.

Barron B 2006. Interest and Self-Sustained Learning as Catalysts of Development: A Learning Ecology Perspective. Human Development Paper, 49: 193-224.

Borda FO 1995. Research for social justice: some north-south convergences. Southern Sociological meeting in Atlanta. www.comm-org.wisc.edu Accessed September 21, 2013.

Braun D 2013 (May, 30). Where the Millennium Development Goals Fell Short: Valuing Nature. Conservation International. 
Brown DL 2003. Challenges for Rural America in the 21st Century. University Park, PA:

Pennsylvania State University Press.

Bryant JA 2010. Dismantling rural stereotypes. Educational Leadership, 54-58.

Bull KS, Warner MM, Yellin D, Robinson DW and Neuberger GC 1989. Attitudes concerning extended teacher education programs: A rural/urban comparison. Research in Rural Education, 5(3):51-56.

Calderwood PE 2003. Toward a professional community for social justice. Journal of Transformative Education, 1:301-320.

Chilisa B, Mafela L and Preece J 2003. Educational research for sustainable development. Gaborone: Lightbooks.

Corbett M 2007. Learning to leave: The irony of schooling in a coastal community. Halifax: Fernwood Publishing Company.

DoE (Department of Education) 2005. Reflections on rural education in South Africa. Pretoria: Government Printers.

Department of Rural Development and Land Reform 2010. Strategic Plan 2010-2013. Pretoria: Government Printers.

Dold JC and Chapman RA 2012. Hearing a voice: Results of a Participatory Action Research study. Child Family Studies, 22:512.

Du Toit A 2013. Real Acts, Imagined Landscapes: Reflections on the Discourses of Land Reform in South Africa after 1994. Journal of Agrarian Change, 13(1):16-22.

Dworski-Riggs D and Langhout RD 2010. Elucidating the power in empowerment and the participation in participatory action research: A story about research team and elementary school change. American Journal of Community Psychology, 45:215-230.

Eppley K 2009. Rural schools and the highly qualified teacher provision of No Child Left Behind: A critical policy analysis. Journal of Research in Rural Education, 24(4):1-14.

Fraser N 1997. Justice interuptus: Critical reflections on the 'postsocialist' condition. New York: Routledge.

Fraser N 2008. Scales of justice: Reimagining political space in a globalising world. Cambridge: Polity Press.

Frattura EM and Tropinka C 2006. Theoretical underpinnings of separate educational programs: The social justice challenge continues. Education and Urban Society, 38: 327-344.

Frey LK, Pearce WB, Pollock MA, Artz L and Murphy BAO 1996. Looking for justice in all the wrong places: On a communication approach to social justice. Communication Studies, 47: 110-127.

Gerwitz S 1998. Conceptualising social justice in education: Mapping the territory. Journal of Education Policy, 13: 469-484.

Gerwitz S, Ball SJ and Bowe R 1995. Markets, choice and equity in education. Buckingham: Open University Press. 
Goldfarb KP and Grinberg J 2002. Leadership for social justice: Authentic participation in the case of a community centre in Caracas, Venezuela. Journal of School Leadership, 12: 157-173.

Halsey RJ 2009. Australia's sustainability: a new policy front for rural education? Education in Rural Australia, 19(2): 1-7.

Hargreaves LM 2009. Respect and responsibility: Review of research on small rural schools in England. International Journal of Educational Research, 48: 117-128.

Hayward C R 2000. De-facing power. Cambridge: Cambridge University Press.

Hlalele D 2012. Social justice and rural education in South Africa. Perspectives in Education, 30(1): 111-118.

Horkheimer M 1982. “The End of Reason.” In AEG Arato (ed). The Essential Frankfurt School Reader. New York: Continuum International Publishing Group.

International Planning Committee for Food Security 2007. Definition of food sovereignty. Declaration of Nyéléni.

Judge TA, Erez A, Bono JE and Thoresen CJ 2002. Are measures of self-esteem, neuroticism, locus of control, and generalized self-efficacy indicators of a common core construct? Journal of Personality and Social Psychology, 83(3):693-710.

Kalaoja E and Pietarinen J 2002. Characteristics of Finnish small rural schools - what can we learn from learning and instruction by researching small rural schools? In book E Kalaoja (ed.) Viewpoints on village schools and their development. University of Oulu. Publications of the Kajaani Department of Teacher Education. Series A: Research Reports 21: 3-17.

Kalaoja E and Pietarinen J 2009. Small rural primary schools in Finland: A pedagogically valuable part of the school network. International Journal of Educational Research, 48:109-116.

Kose BW 2009. The Principal's role in Professional Development for Social Justice: An Empirically-based Transformative Framework. Urban Education, 44: 628-663.

Lee R 2007. Food security and food sovereignty. Centre for Rural Economy Discussion Paper Series No. 11.

Lloyd A 2000. Partnership: Cautious commitment or fruitless devotion? A case of redefining the relationship between the community sector and the state. Galway: Community Workers Co-operative.

Ludlow BL and Brannan SA 2010. Distance education programs preparing personnel for rural areas: Current practices, emerging trends, and future directions. Rural Special Education Quarterly, 29:4-15.

Lybeck ER 2010. The Critical Theory of Lewis Mumford. The International Journal of Interdisciplinary Social Sciences, 5(1): 91-102.

Mahlomaholo MG 2009. Decolonising the Contexts of the Subaltern Academic Teacher Communities through the Genealogical Method. In Lavia, J and Moore, M (eds). CrossCultural Perspectives on Policy and Practice: Decolonising Community Contexts. London: Routledge. 
Malhoit GC 2005. Providing rural students with a high quality education: The rural perspective on the concept of educational adequacy. Arlington: Rural Education and Community Trust.

Mapesela M, Hlalele D and Alexander G 2012. Overcoming adversity: A holistic response to creating sustainable rural learning ecologies. Journal of Human Ecology, 38(2): 91-103.

McQuaide S 2009. Making education equitable in rural China through distance learning. International Review Research in Open and Distance Learning. 10: 1-21.

Marsden T 1998. New rural territories: regulating the differentiated rural spaces. Journal of Rural Studies, 14(1): 107-117.

Marsden T and Sonnino R 2008. Rural development and the regional state: Denying multifunctional agriculture in the UK. Journal of Rural Studies, 24:422-431.

McGregor SLT 2003. A critical discourse analysis - a primer [Online] Available at url: http://www.kon.org/archives/forum/15-1/mcgregorcda.html. Accessed on 23 May 2009.

Mollenkopf DL 2009. Creating highly qualified teachers: Maximizing university resources to provide professional development in rural areas. The Rural Educator, 30(3): $\mathrm{x}-\mathrm{xx}$.

Nkambule T, Balfour RJ, Pillay G and Moletsane R 2011. Rurality and rural education: Discourses underpinning rurality and rural education research in South African postgraduate education research 1994-2004. South African Journal of Higher Education, 25(2): 341-357.

Nkoane MM 2013. Critical emancipatory research for social justice and democratic citizenship. Perspectives in Education, 30(4): 98-104.

North CE 2006. More than words? Delving into substantive meaning(s) of 'social justice' in education. Review of Educational Research, 76: 507-535.

Pers. Comm. 29 May 2013. Discussion with Thomas Torbjonnson in Uppsala, Sweden.

Robinson V, Blaine T and Pace NJ 2004. Voices in the hallway: Three rural Iowa schools. The Rural Educator, 25(3):1-4.

Sabbagh C 2003. The dimension of social solidarity in distributive justice. Social Science Information, 42: 255-276.

Sauvageot C and da Graća PD 2007. Using indicators in planning education for rural people: $A$ practical guide. Paris: International Institute for Educational Planning.

Seepe S 2004. Towards an African identity of higher education. Pretoria: Vista University Press and Skotaville Press.

Shamah D and MacTavish KA 2009. Rural research brief: Making room for place-based knowledge in rural classrooms. The Rural Educator, 30(2): 1-4.

Shibeshi A 2006. Education for rural people in Africa. Paris: FAO/IIEP.

Siemens G 2003. Learning ecology, communities, and networks: extending the classroom. http://www.elearnspace.org/Articles/learning_communities.htm. Accessed on October 9, 2013. 
Solomon RC and Murphy MC 2000. What is justice? Classic and Contemporary Reading. New York: Oxford University Press.

Solomon A 2012. Sustainability options for resource based rural communities: Literature review. Athabasca University.

Spreen CA and Vally S 2006. Education rights, education policies and inequality in South Africa. International Journal of Educational Development, 26: 352-362.

Tikly L 2010. A roadblock to social justice? An analysis and critique of the South African education roadmap. International Journal of Educational Development, doi:10.1016/ijeduved.2010.06.008.

UNISA (University of South Africa) 2011. We grow our own timber. www.unisa.ac.za/iisa. Accessed on December 2, 2013.

Wals AEJ and Corcoran PB (Eds) 2012. Learning for sustainability in times of accelerating change. Wageningen, Netherlands: Wageningen Academic Publishers.

Wals AEG, van der Hoeven M and Blanken H 2009. The acoustics of social learning: designing learning processes that contribute to a more sustainable world. The Netherlands: Wageningen Academic Publishers.

Williams R, Karousou R and Mackness J 2011. Emergent Learning and Learning Ecologies in Web 2.0. International Review of Research in Open and Distance Learning, 12:3: 3959.

Wilson EO 1998. Consilience: The unity of knowledge. New York: Vintage Books.

Wright A 2012. Creating and sustaining an "effective" rural school: The critical triad leadership, curriculum, and community. Unpublished doctoral thesis. University of Otago: Otago. 